\title{
The Level of Integration of Bancassurance Products of Financial Groups Erste Group Bank, UniCredit Group and KBC Group in Selected Countries
}

\author{
Lenka Přečková1, Eva Vávrová2 \\ ${ }^{1}$ Silesian University in Opava \\ School of Business Administration in Karvina, Department of Finance and Accounting \\ Univerzitní nám. 1934/3, 73340 Karvina, Czech Republic \\ E-mail: preckova@opf.slu.cz \\ 2 Masaryk University \\ Faculty of Economics and Administration, Department of Finance \\ Lipová 507/41a, 60200 Brno, Czech Republic \\ E-mail: eva.vavrova@econ.muni.cz
}

\begin{abstract}
This paper will evaluate the current state of cooperation between banks and insurance companies as well as internal integration of bancassurance products in financial groups Erste Group Bank, UniCredit Group and KBC Group. The evaluation is performed as of September, 2016. There shall be selected ten countries which are located in Central and Eastern Europe: Czech Republic, Slovak Republic, Poland, Hungary, Romania, Bulgaria, Croatia, Bosnia and Hercegovina, Slovenia and Serbia. The aim of this paper is to determine whether or not there is a similarity in integrated financial products belonging to different financial groups in individual countries. This paper will apply a qualitative research approach. A theoretical base for evaluating the level of cooperation between banks and insurance companies and for evaluation of an internal integration of bancassurance products will be set in the paper. The theoretical base is to be compared with the current bancassurance practice within financial groups and countries. To evaluate bancassurance practice, this paper shall use data available on web sites, financial and annual reports of financial institutions. The qualitative research is to contain a detailed analysis, sorting and comparison of set theoretical bases. The financial groups show differentness as far as integration is concerned. The research led to the conclusion that there is a similarity in bancassurance products which are offered in evaluated countries. A dissimilarity was found in the level of integration of bancassurance products.
\end{abstract}

Keywords: bancassurance product, financial group, insurance group, integration of group, integration of product

JEL codes: G21, G22

\section{Introduction}

Insurance industry and insurance institutions have witnessed many changes over the past few years. New ways of how products are offered and how they are sold to clients are some of these changes. It is namely bancassurance and virtual insurance institutions, i.e. using the internet. Economy is strongly affected by globalization and banking and insurance industry, or more precisely banking and insurance institutions, 
are no exceptions. Conducting various money transactions leads to more and more connections between banks and insurance companies. Their activities and operations become interwoven. There are now two players conducting insurance operations on the financial market and insurance market: insurance institutions and banks.

The theory of bancassurance is dealt with by many authors. When studying these theories, it is necessary to distinguish between those approaching bancassurance from the product perspective and those doing so from the operation (product sales) perspective. Both approaches have something in common, however, and that is an internal integration from the perspective of the bank and insurance product and from the perspective of the bank and insurance operations. From the product perspective, bancassurance is often debated about with the term neither being unequivocally defined nor really accepted. Bancassurance from the operation perspective is related to how banks and insurance companies cooperate and how this cooperation develops; it is also related to the creation of variously integrated financial institutions. Authors offer different theoretical perspectives as well as different ways of sorting these kinds of integration.

For these reasons, it seems to be essential before to proceed to conduct the research, to introduce a relevant theory of bancassurance and consequently set a theoretical base for the qualitative research evaluation of the financial practice. The crucial part of the qualitative research will be comparing theory and practice. The analysis of bancassurance functioning in practice requires that information and data is collected from the financial institutions, which is extremely demanding and difficult. Neither banks nor insurance companies publish information about bancassurance, as a distribution channel, in an extent that might be anticipated supposing how much theory knows about this issue.

The aim of this paper is to determine whether or not there is a similarity in integrated financial products belonging to different financial groups in individual countries. This paper wants to discover more about the level of integration of financial institutions (bank and insurance company) and also financial products (bank and insurance product). The research will be conducted evaluating the financial groups: Erste Group Bank (hereinafter referred to as EGB), UniCredit Group (hereinafter referred to as UCG) and KBC Group (hereinafter referred to as KBCG). The research is primarily focused on the region of Central and Eastern Europe (CEE). The research will evaluate countries located in the CEE region in which the financial group EG operates: the Czech Republic (CZ), Slovak Republic (SK), Poland (PL), Hungary (HU), Romania (RO), Bulgaria (BG), Croatia (HR), Bosnia and Hercegovina (BA), Slovenia (SI) and Serbia (RS).

The first part of paper briefly characterizes the selected financial groups from the perspective of the origin and development of banks' and insurance companies' cooperation. It describes and compares banks and cooperating insurance companies within financial groups from a shareholders' viewpoint. Next part brings an analysis of bancassurance practice. The research includes an analysis of bancassurance products which are offered by banks. Finally, the discussion over ascertained results is provided. 


\section{Literature Review}

The bancassurance phenomenon that is unquestionably one of the most important trends in the evolution of the European financial services industry can be considered as a consequence of the progressive deregulation of the regulatory barriers to financial conglomerates (Clipici and Bolovan, 2012). Daňhel, Ducháčková and Radová (2008) consider creation of financial groups in the Czech Republic as a trend which shall not be a bank-insurance strategy in the pure form. Daňhel, Ducháčková and Radová (2007) point out that bancassurance is a significant factor stabilizing business risks of both sectors. On the other hand, they also mention that bancassurance is a very specific hinderer of further integration and further development of bancassurance products may be dependent on increasing number of wealthier clients who prefer more sophisticated "tailored" products.

According to Čejková, Martinovičová and Nečas (2011), bancassurance is a relatively new type of services and operations which will probably further develop in the future. From the clients' vantage point, a big development in bancassurance may be a step backwards. The main disadvantages may be found in simplifying and unification of insurance products. Bancassurance is present in every developed economy and it opens up an immense space for a non-price competition among banks.

According to Ricci (2012) "It is not possible to identify an ideal form of bancassurance, because the success of cooperation between banks and insurance companies depends upon many factors, both market-based and strategic or operational. Bancassurance can experience alternate fortunes across time and countries, but remains a central current phenomenon of the modern financial service industry."

Beltratti and Corvino (2008) emphasize the development of bancassurance can be influenced by various factors. Banks and insurance companies maintain structural differences, limited the extent of convergence due to factors as demographics, the structure of liabilities, the scale of operations, regulation and accounting practices and distribution channels.

Hoschka (1994) speaks about six key factors which influence banks' decision whether to enter the life insurance sector. There are: demographic changes, economic environment, savings trends, differential tax treatment, growth performance and potential, insurance penetration and saturation.

According to Daňhel, Ducháčková and Radová (2007), the common denominator of all available definitions of bancassurance is the structured sale of combined financial products to targeted groups of clients. A very high effectiveness can be found in internally interconnected bancassurance product which represents an additional utility value for the end user of such a product as it is tailored for him based on what this end user needs.

According to Řezáč (2009), bancassurance can be defined as "effective creation and distribution of bank and insurance products for the common group of clients". When selling bancassurance products, the more the insurance products is rooted into the 
pillar product of a financial institution, the more it will become its organic part and the better sales it will achieve (Lím, 2012).

Illetško (2003) also warns that the term of bancassurance is often defined and understood incorrectly. According to him, bancassurance cannot be confused with what should be referred to as cross-selling. The sale channel of bancassurance can be understood as a channel of selling the financial product which is internally integrated with the financial product and it brings an addition utility value for the end client of the financial institution. The insurance product is sold as a collective policy. An insurance company and a financial institution conclude a collective policy agreement which directly specifies conditions of the policy including insurance conditions.

The conclusion (Stracia, 2012) about the actual areas of the bancassurance products is: "The actual areas concern the life insurance, the payment protection insurance and the home insurance whereas the new areas are represented by the car insurance, the travel insurance, the pet insurance and the health insurance."

Ducháčková and Daňhel (2010) speak about further integration of financial institutions. Integration of financial institutions can be in the form of a total integration, a partial integration with a parent universal bank, an integration with a banking or insurance parent company or a holding structure. The total integration is the highest form of integration. It means an integration of various financial services within one company. All activities are then financed using one capital. This form of integration is more or less constructed by theory. A partial integration with a parent universal bank leads to an organization of financial conglomerates in which the universal bank covers commercial and also investment banking. Utilizing daughter companies, this conglomerates offer other financial services including insurance policies. Integration with a banking or insurance parent company is a type of organization in which the parent company owns, either completely or partially, its daughter companies and through these it provides clients with financial services (investment banking, insurance policies, other financial services). Finally, a holding structure is a type of organization in which an independent parent company owns all or most shares in independent daughter companies and each of them offers independent financial services.

\section{Methodology and Data}

The research problem originates from the area of bancassurance practice, particulary from the area of operation of bancassurance models and integrated bancassurance products. The research tries to discover how bancassurance actually operates whilst comparing theory with practical conclusions. A theoretical basis, which is related to the defined problem, shall be set first, and it shall be compared with bancassurance practice. The evaluation of bancassurance practice shall be based on an analysis and comparison of information available in annual reports (2015) and current information found on websites of financial institutions (2016). The research works with nonnumeric data, analyses practice and compares it with theoretical bases. The aim of this article and theoretical bases shall be used to form a research questions. This is a standard procedure used in qualitative research (Punch, 2008; Disman, 1993). 
The aim of this paper is to determine whether or not there is a similarity in integrated financial products belonging to different financial groups in individual countries. Qualitative research replies to a research question related to a defined objective. Is the level of integration of a bancassurance product of selected financial groups in individual countries similar? Which countries show the strongest integration of a bancassurance product? What level of integration of the bancassurance products do the selected financial groups actually have?

In accordance with Hendl (2005), the qualitative research applied a deductively used theory relation. The research used conclusions made by Ducháčková and Daňhel (2010) and by Illetško (2003).

In order to be able to evaluate the integration of the financial group, the sorting method created by Ducháčková and Daňhel (2010) shall be used. This paper shall focus on and evaluate bancassurance from the perspective of internal integration as defined by Illetško (2003).

In order to solve the research questions, the main method of qualitative researches shall be applied, i.e. analysis - synthesis (Hendl, 2005). There shall be analyzed financial groups operating in individual countries from the perspective of property interconnection, and bancassurance products from the perspective of an integration of an insurance and banking product. The analysis is performed in the area of currently existing bancassurance practice in individual selected countries. Consequently, all findings shall be described, and the main principles of how bancassurance practice operates shall be evaluated.

The first part of this research shall briefly characterize the selected financial groups from the perspective of the origin and development of banks' and insurance companies' cooperation. It describes and compares banks and cooperating insurance companies within financial groups from a shareholders' viewpoint. Data was taken from the web sites and annual reports of financial institutions as of 2015 .

The final part of research shall be in form of an analysis of bancassurance practice. The research shall include an analysis of bancassurance products which are offered by banks. Information is taken only from web sites of individual insurance companies as annual reports do not include this sort of information. Finally, this paper shall discuss over ascertained results and shall answer the previously set research questions.

\section{Results and Discussion}

\subsection{Integration of the Financial Groups EGB, UCG a KBCG}

Erste Bank was founded in 1819 as the first Austrian savings bank. EGB went public in 1997 with a strategy to expand its retail business into CEE. Since then EGB has grown through numerous acquisitions and organically to become one of the largest financial services providers in the Eastern part of the EU in terms of clients and total assets. "DIE ERSTE österreichische Sparkasse - Bank AG" merged with "GiroCredit Bank Aktiengesellschaft der Sparkassen" and changed its name in "Erste Bank der oesterreichischen Sparkassen AG" operating under the name "Erste Bank" in 1997. 
Customer base was 600.000 . The new bank went public at the Vienna Stock Exchange in November 1997. The important changes were in 2008. The separation of the Holding and Erste Bank Oesterreich took legal effect. The registered company name of the Holding is "Erste Group Bank AG". Ever since, the registered company name of splitoff Erste Bank Oesterreich is "Erste Bank der oesterreichischen Sparkassen AG".

While the banking group's history dates back as far as 1473, in which year Rolo Banca was created, the contemporary history of UCG begins from a merger of nine leading Italian banks, the subsequent integration with the German HVB Group and, most recently, with the Italian Capitalia. In 1999, acquisition of Bank Pekao of Poland launched the Group's expansion (at that time, under the name UniCredito Italiano) into CEE. Growth continued over the next few years with purchase of the Pioneer Investments group, the subsequent formation of Pioneer Global Asset Management, and then further strategic acquisitions gradually carried out in Bulgaria, Slovakia, Croatia, Romania, the Czech Republic and Turkey. UniCredit merged with the German group HVB in 2005. By merging in 2007 with Capitalia, the third-largest Italian banking group, UCG further consolidated and strengthened its position in one of its most important markets, Italy.

KBC Group was formed in 1998 after the merger of two Belgian banks (Kredietbank and CERA Bank) and a Belgian insurance company (ABB Insurance). In 1999 the group embarks upon its policy of expansion in CEE with the acquisition of ČSOB (in the Czech Republic and Slovakia). The group continues to expand its position in the banking and insurance markets of CEE by acquiring banks and insurance companies in Poland, Hungary, the Czech Republic and Slovakia, becoming one of the top three players in the region's financial sector (2000 -2005). The bancassurance model is gradually introduced to the home markets in CEE. The KBC Bank and Insurance Holding Company merges with its parent company (Almanij) to create KBC Group NV (2005). KBC Group sold the activity in Poland in 2013. KBC group is essentially structured around three business units, which focus on the local business and are expected to contribute to sustainable earnings and growth. The business units are Belgium, the Czech Republic and International Markets. KBC Group controls two underlying companies: KBC Bank and KBC Insurance. KBC GROUP NV and its daughter companies form an integrated bank and insurance group providing services mainly to clients of retail and private banking, as well as to medium-sized enterprises and to mid-cap companies.

\subsection{Comparison of Integration in Financial Groups EGB, UCG and KBCG}

Table 1 compares banks from the viewpoint of ownership within financial groups EGB, UCG and KBCG. Knowing a financial group and a country, it is possible to locate an influencing commercial bank and its majority owner. It is obvious from the table that some financial groups are active only in some of the selected countries. The largest province is held by UCG (all selected countries). KBCG operates in fewest countries (it operates only in four of the selected countries).

In each country there is one bank operating within the EGB. In all these countries, the majority shareholder is EGB which has the smallest share in HR (59\%) and RS (74 
\%). In countries HR and RS, Steiermärkische Bank and Sparkasse is the second most significant shareholder of the bank. In HR, this share represents $41 \%$. In RS, it is $26 \%$.

In each country except BA, there is one bank operating within the UCG. In all countries (except Poland), the bank is owned by UCB Austria, with a majority share. UCB Austria is owned by UCG having nearly a $100 \%$ share. Bank Pekao (PL) is an exception. It is owned directly by UCG holding a share of $50.10 \%$. The remaining shares are held by minority shareholders. HR is the only country with an obvious share of a commercial insurance company. Zagrebačka Bank (HR) is owned by the Allianz SE group with a share of $11 \%$. In $B A$, there are two banks operating within the UCG, one is owned by UCB Austria, the other is owned by a Croatian Bank, Zagrebačka Bank.

Table 1 Banks and their majority shareholders operating within financial groups EGB, UCG and KBCG

\begin{tabular}{|c|c|c|c|c|c|c|}
\hline \multirow[b]{2}{*}{ Country } & \multicolumn{2}{|c|}{ EGB } & \multicolumn{2}{|c|}{ UCG } & \multicolumn{2}{|c|}{ KBCG } \\
\hline & Bank & $\begin{array}{c}\text { Main } \\
\text { owner } \\
(>50 \%)\end{array}$ & Bank & $\begin{array}{c}\text { Main } \\
\text { owner } \\
(>50 \%)\end{array}$ & Bank & $\begin{array}{c}\text { Main } \\
\text { owner } \\
(>50 \%)\end{array}$ \\
\hline CZ & $\begin{array}{c}\text { Česká } \\
\text { spořitelna }\end{array}$ & EGB & \multirow{2}{*}{$\begin{array}{l}\text { UniCredit } \\
\text { Bank }\end{array}$} & \multirow{2}{*}{$\begin{array}{l}\text { UCB } \\
\text { Austria }\end{array}$} & ČSOB & KBC Bank \\
\hline SK & $\begin{array}{l}\text { Slovenská } \\
\text { sporitel'ňa }\end{array}$ & EGB & & & ČSOB & KBC Bank \\
\hline PL & & & $\begin{array}{l}\text { Bank } \\
\text { Pekao }\end{array}$ & UCG & & \\
\hline HU & $\begin{array}{c}\text { Erste Bank } \\
\text { Hungary }\end{array}$ & EGB & $\begin{array}{c}\text { UniCredit } \\
\text { Bank }\end{array}$ & $\begin{array}{c}\text { UCB } \\
\text { Austria }\end{array}$ & K\&H Bank & KBC Bank \\
\hline RO & $\begin{array}{c}\text { Banka } \\
\text { Comerciala } \\
\text { Romana }\end{array}$ & EGB & $\begin{array}{l}\text { UniCredit } \\
\text { Bank }\end{array}$ & $\begin{array}{c}\text { UCB } \\
\text { Austria }\end{array}$ & & \\
\hline BG & & & $\begin{array}{l}\text { UniCredit } \\
\text { Bulbank }\end{array}$ & $\begin{array}{c}\text { UCB } \\
\text { Austria }\end{array}$ & CITIBANK & KBC Bank \\
\hline HR & $\begin{array}{c}\text { Erste\& } \\
\text { Steiermärki } \\
\text { rche Bank }\end{array}$ & EGB & $\begin{array}{c}\text { Zagrebačk } \\
\text { a Banka }\end{array}$ & $\begin{array}{c}\text { UCB } \\
\text { Austria }\end{array}$ & & \\
\hline & & & $\begin{array}{l}\text { UniCredit } \\
\text { Bank }\end{array}$ & $\begin{array}{c}\text { Zagrebačka } \\
\text { Banka }\end{array}$ & & \\
\hline BA & & & $\begin{array}{c}\text { UniCredit } \\
\text { Bank } \\
\text { Banja } \\
\text { Luka } \\
\end{array}$ & $\begin{array}{c}\text { UCB } \\
\text { Austria }\end{array}$ & & \\
\hline SI & & & $\begin{array}{l}\text { UniCredit } \\
\text { Banka } \\
\text { Slovenija }\end{array}$ & $\begin{array}{c}\text { UCB } \\
\text { Austria }\end{array}$ & & \\
\hline RS & $\begin{array}{c}\text { Erste Bank } \\
\text { Novi Sad }\end{array}$ & EGB & $\begin{array}{l}\text { UniCredit } \\
\text { Bank }\end{array}$ & $\begin{array}{c}\text { UCB } \\
\text { Austria }\end{array}$ & & \\
\hline
\end{tabular}

Source: Summarized by authors based on website and annual report of financial institutions

In the financial group KBCG, KBC Bank is the only shareholder (owning $100 \%$ of shares). KBC Bank is owned ( $100 \%$ ownership) by its parent company KBC Group.

Now, it is necessary to present insurance companies which cooperate with banks within financial groups as well as within countries. Majority shareholders shall be presented as well. See Table 2. 
EGB's cooperation with insurance companies in the selected countries has been based on a strategic partnership (since 2008) with the insurance group VIG. This partnership's consequence is offering bancassurance products. Interconnection of property (between the bank and the insurance company) is not observable. In five countries ( $\mathrm{CZ}, \mathrm{SK}, \mathrm{HR}, \mathrm{HU}, \mathrm{RO})$, Erste Bank owns shares (5\%) of the insurance company. The most observable similarity of how EGB and VIG are organized is in countries $\mathrm{CZ}$ and SK, followed by countries HU and RO.

Table 2 Cooperating insurance companies within the financial groups EGB, UCB and KBCG as well as their majority shareholders

\begin{tabular}{|c|c|c|c|c|c|c|}
\hline \multirow[b]{2}{*}{ Country } & \multicolumn{2}{|c|}{ EGB } & \multicolumn{2}{|c|}{ UCG } & \multicolumn{2}{|c|}{ KBCG } \\
\hline & $\begin{array}{c}\text { Insurance } \\
\text { company }\end{array}$ & $\begin{array}{c}\text { Main } \\
\text { owner } \\
(>50 \%)\end{array}$ & $\begin{array}{c}\text { Insurance } \\
\text { company }\end{array}$ & $\begin{array}{c}\text { Main owner } \\
(>50 \%)\end{array}$ & $\begin{array}{c}\text { Insurance } \\
\text { company }\end{array}$ & $\begin{array}{c}\text { Main } \\
\text { owner } \\
(>50 \%)\end{array}$ \\
\hline $\mathbf{C Z}$ & $\begin{array}{l}\text { Kooperativa } \\
\text { Pojištovna } \\
\text { České } \\
\text { spořitelny }\end{array}$ & $\begin{array}{l}\text { VIG } \\
\text { VIG }\end{array}$ & \multirow{2}{*}{$\begin{array}{c}\text { Generali } \\
\text { Allianz } \\
\text { Česká poj. } \\
\text { AXA } \\
\text { ERGO } \\
\text { Union } \\
\text { CARDIF }\end{array}$} & \multirow{2}{*}{$\begin{array}{c}\text { Generali CEE } \\
\text { Allianz SE } \\
\text { Generali CEE } \\
\text { SOCIETE } \\
\text { ERGO Austria } \\
\text { Achmena } \\
\text { PNP Paribas } \\
\text { Cardif }\end{array}$} & ČSOB & $\begin{array}{c}\mathrm{KBC} \\
\text { Insurance }\end{array}$ \\
\hline SK & $\begin{array}{l}\text { Kooperativa } \\
\text { Pojišt'ovna } \\
\text { Slovenskej } \\
\text { sporitel'ně }\end{array}$ & $\begin{array}{l}\text { VIG } \\
\text { VIG }\end{array}$ & & & ČSOB & $\begin{array}{c}\mathrm{KBC} \\
\text { Insurance }\end{array}$ \\
\hline PL & & & $\begin{array}{l}\text { Allianz } \\
\text { ERGO }\end{array}$ & $\begin{array}{c}\text { Allianz SE } \\
\text { ERGO Group }\end{array}$ & & \\
\hline HU & $\begin{array}{l}\text { Erste } \\
\text { Union }\end{array}$ & $\begin{array}{l}\text { VIG } \\
\text { VIG }\end{array}$ & $\begin{array}{l}\text { Generali } \\
\text { ERGO } \\
\text { CIG }\end{array}$ & $\begin{array}{c}\text { Generali CEE } \\
\text { ERGO Austria } \\
\text { Domestic } \\
\text { private } \\
\text { individual }\end{array}$ & $\mathrm{K} \& \mathrm{H}$ & $\begin{array}{c}\mathrm{KBC} \\
\text { Insurance }\end{array}$ \\
\hline RO & $\begin{array}{c}\text { Omniasig } \\
\text { BCR }\end{array}$ & $\begin{array}{l}\text { VIG } \\
\text { VIG }\end{array}$ & ERGO & ERGO Austria & & \\
\hline BG & & & $\begin{array}{c}\text { Allianz } \\
\text { Generali }\end{array}$ & $\begin{array}{l}\text { Allianz Hold. } \\
\text { Generali CEE }\end{array}$ & DZI & $\begin{array}{c}\text { KBC } \\
\text { Insurance }\end{array}$ \\
\hline HR & Erste & VIG & $\begin{array}{c}\text { Allianz } \\
\text { BNP Paribas }\end{array}$ & $\begin{array}{l}\text { Allianz SE } \\
\text { PNP Group }\end{array}$ & & \\
\hline RA & & & Not stated & Not stated & & \\
\hline & & & Not stated & Not stated & & \\
\hline SI & & & $\begin{array}{c}\text { ERGO } \\
\text { Generali }\end{array}$ & $\begin{array}{l}\text { ERGO Group } \\
\text { Generali CEE }\end{array}$ & & \\
\hline RS & $\begin{array}{l}\text { Wiener } \\
\text { Städtische }\end{array}$ & VIG & $\begin{array}{l}\text { Generali } \\
\text { Wiener } \\
\text { Städtische }\end{array}$ & $\begin{array}{c}\text { Generali CEE } \\
\text { VIG }\end{array}$ & & \\
\hline
\end{tabular}

Source: Summarized by authors based on website and annual report of financial institutions

There is no interconnection of property between UCG and cooperating insurance companies. UniCredit Bank has been offering bank products and services as "UniCredit Bank Czech Republic and Slovakia, a. s." (UCB CZ-SK) in the Czech Republic and Slovakia since 2013. The insurance group ERGO has concluded a strategic cooperation agreement with UCG (2007) in all countries except for BG, BA and RS. In these countries, ERGO has not set up a subsidiary company or a branch. Table 2 shows that there is no obvious cooperation with ERGO in Croatia (HR). At the same time, ERGO 
Austria has set up a subsidiary company in Croatia. Banks' cooperation with insurance companies is not uniform. Banks tend to cooperate, despite their strategic agreements, with other insurance companies. Considering that the UCG has concluded a strategic agreement with EGRO Group, one might expect that these entities will work towards an exclusive partnership. The reality is different however. The only similar aspect can be found in the fact that in all countries except for BG, BA and RS, there is a cooperation with third insurance companies. These are namely ERGO, Allianz and Generali. Generali cooperates with UCG in all selected countries. Allianz cooperates with UCG in all selected countries except BA and RS. In some countries (CZ, SK, HU, $\mathrm{HR}$ and RS), there can be found more insurance companies. CZ-SK are specific in the fact that there is the widest range of cooperating insurance companies. This is probably caused be the cooperation of UCB CZ-SK with the company PARTNERS.

The financial group KBCG operates only in four of the selected countries. In every country, there is only one cooperating insurance company which is a daughter company of KBCG (KBC Insurance is completely owned by KBCG). The financial group operates as an integrated bank and insurance company.

\subsection{Comparison of Bancassurance Products of Financial Groups EGB, UCG and KBCG}

In Table 3, there is presented a comparison of bancassurance products within financial groups and countries. Bancassurance products are evaluated based on their range (number), availability of insurance products for bank's clients, availability of general contracts as well as availability of discounts and other benefits for clients of the bank.

Most insurance products which are offered by banks within EGB can be described as integrated. In the Czech Republic and in Slovakia, banks offer also products (property insurance, life insurance), which show less integration. In Romania, no interconnection of property can be observed. In summary, the strongest interconnection of products within EGB takes place on Slovakian financial market. The second most significant integration of products is in the Czech Republic, followed by Hungary.

Insurance products offered by banks within UCG show signs of integration. Clients are offered various kinds of discounts. Evaluation cannot be performed for countries BA and SI because relevant data cannot be accessed. Based on how many products and how many general contracts are offered, the most developed countries as far as integration is concerned are the Czech Republic and Slovakia (within UCG, they are considered one subject), followed by BG, HU and PL.

Insurance products offered by banks within KBCG can be described as integrated bancassurance products. The countries HU and BG offer insurance products only with relation to bank products. The Czech Republic and Slovakia offer not only exclusive integrated products but also other insurance products not related to bank products. In Slovakia (SK), all financial products are offered within the brand ČSOB, though benefits for clients are not specified on the official website. In the Czech Republic, integration of a banking and insurance product is not completely clear. Some insurance 
products are linked to bank products but there is a range of products without apparent benefits.

Table 3 Bancassurance products offered by financial groups EGB, UCB and KBCG

\begin{tabular}{|c|c|c|c|c|c|}
\hline Country & $\begin{array}{c}\text { Financial } \\
\text { Group }\end{array}$ & $\begin{array}{l}\text { Number } \\
\text { of ins. } \\
\text { product }\end{array}$ & $\begin{array}{l}\text { Ins. product } \\
\text { for client } \\
\text { of bank }\end{array}$ & $\begin{array}{l}\text { General } \\
\text { contract }\end{array}$ & $\begin{array}{l}\text { Discounts } \\
\text { and other } \\
\text { advantages }\end{array}$ \\
\hline \multirow{3}{*}{ CZ } & ERSTE & 11 & YES & YES & YES \\
\hline & UCB & 7 & YES & YES & YES \\
\hline & $\mathrm{KBC}$ & 8 & YES & & YES \\
\hline \multirow{3}{*}{ SK } & ERSTE & 8 & YES & YES & \\
\hline & UCB & 5 & YES & YES & YES \\
\hline & KBC & 4 & YES & YES & \\
\hline \multirow[t]{2}{*}{ PL } & UCB & 5 & YES & & YES \\
\hline & ERSTE & 5 & YES & & \\
\hline \multirow[t]{2}{*}{ HU } & UCB & 6 & YES & & YES \\
\hline & KBC & 5 & YES & & YES \\
\hline \multirow{2}{*}{ RO } & ERSTE & 7 & NOT STATED & & \\
\hline & UCB & 1 & YES & & \\
\hline \multirow{2}{*}{ BG } & UCB & 3 & YES & YES & YES \\
\hline & KBC & 4 & & & \\
\hline \multirow{2}{*}{ HR } & ERSTE & 3 & & & \\
\hline & UCB & 6 & YES & & \\
\hline BA & UCB & NOT STATED & & & \\
\hline SI & UCB & NOT STATED & & & \\
\hline \multirow{2}{*}{ RS } & ERSTE & 4 & YES & & \\
\hline & UCB & 2 & YES & & \\
\hline
\end{tabular}

Source: Summarized by authors based on website of financial institutions (2016)

\section{Conclusions}

The aim of this paper is to determine whether or not there is a similarity in integrated financial products belonging to different financial groups in individual countries. Qualitative research replies to a research question related to a defined objective.

Is the level of integration of a bancassurance product of selected financial groups in individual countries similar? Which countries show the strongest integration of a bancassurance product? What level of integration of the bancassurance products do the selected financial groups actually have? Before answering these questions, it is necessary to recapitulate the types of integration in financial groups. The financial groups EGB, UCG and KBCG show differentness as far as integration is concerned. Within the financial groups EGB and UCG, there is no interconnection of property between banks and insurance companies. Bancassurance products are sold on the basis of a strategic partnership with insurance groups. Inside the EGB group, an exclusive cooperation with VIG is obvious. Inside the UCG group, there is no exclusive cooperation with ERGO. UCG offers products of other insurance companies, especially products of Allianz and Generali. KBCG is an 
integrated bank and insurance group. KBC Group owns two daughter companies (100\% share): KBC Bank and KBC Insurance. Banks in all countries are owned by the company KBC Bank (100\% share). Insurance companies in all countries are owned by KBC Insurance ( $100 \%$ share). KBCG is a financial group with the following type of integration: "partial integration with a parent universal bank."

In all selected countries, integrated insurance products are offered within financial groups. In some countries, information available on companies' websites is unambiguous and annual reports do not provide this kind of information (for example countries BA, SI within UCG; RO within EGB). The research discovered similarity in bancassurance products in individual countries.

What level of integration of the bancassurance products do the selected financial groups actually have? It seems that the main problem making answering this question difficult is that the financial groups do not operate in all evaluated countries. For this reason, the qualitative research itself is unable to univocally answer this question. Based on what has been found, it cannot be concluded that if a financial group offers an integrated product in one of the selected countries, it will offer the same integrated product in another country.

Is the level of integration of a bancassurance product of selected financial groups in individual countries similar? Based on the conducted research, similarity was discovered in countries CZ, SK, HU, BG and PL.

Which countries show the strongest integration of a bancassurance product? Because financial groups do not operate in all selected countries, it is not possible to conduct complex evaluation. All groups operate in countries $\mathrm{CZ}, \mathrm{SK}$ and $\mathrm{HU}$. In these individual countries, the level of integration of products is very similar. BG is specific because EGB does not operate there. This country shows some similarity with countries CZ, SK and HU. Should only the groups UGB and KBCG be compared, BG shows a comparable level with other countries ( $C Z, S K$ and $\mathrm{HU})$.

\section{Acknowledgments}

Research behind this paper was supported by the Czech Science Foundation within the project 16-17796S "Affiliation with financial conglomerate as a determinant of performance and risk of banks".

\section{References}

Beltratti A. and Corvino G. (2009). Why are Insurance Companies Different? The Limits of Converegence among Financial Institucion. The Geneva Papers, 33, pp. 363-388. DOI: $10.1057 /$ gpp. 2008.13.

Clipici, E. and Bolovan, C. (2012). Bancassurance - main insurance distribution and sale channel in Europe. Scientific Bulletin - Economic Sciences, 11(special issue), pp. 54-62.

Čejková, V., Martinovičová, D., Nečas, S. (2011). Poistný trh. Bratislava: Iura Edition. Daňhel, J., Ducháčková, E., Radová, J. (2007). Analýza globálních trendů ve světovém a českém komerčním pojištění. Praha: VŠE. 
Daňhel, J., Ducháčková, E. and Radová, J. (2008). Hlavní závěry z analýzy globálních trendů ve světovém a českém komerčním pojištovnictví. Pojistné rozpravy, 22, pp. 114-118.

Disman, M. (1993). Jak se vyrábí sociologická znalost. Praha: Karolinum.

Ducháčková, E. and Daňhel, J. (2010). Teorie pojistných trhů. Praha: Professional Publishing.

Hendl, J. (2005). Kvalitativní výzkum. Základní metody a aplikace. Praha: Portál.

Hoscha, T. C. (1994). Bancassurace in Europe. London: The MacMillan Press.

Illetško, P. (2003). Bankopojištění, jeho výhody a perspektivy v ČR. Pojistný obzor, 4, pp. 15.

Lím, P. (2012). Bankopoistenie je nielen o spolupráci s bankami. Pojistný obzor, 2, pp. 20-22.

Punch, K. F. (2008). Úspěšný návrh výzkumu. Praha: Portál.

Ricci, O. (2012). The Development of Bancassurance in Europe. In: Fiordelisi, F. and Ricci, O. (eds.): Bancassurance in Europe - Past, Present and Future. Hampshire: Palgrave Macmillan, pp. 5-26.

Řezáč, F. (2009). Marketingové řizení komerční pojištovny. Brno: MU.

Stracia, M. F. (2012). Bancassurance Products. In: Fiordelisi, F. and Ricci, O. (eds.): Bancassurance in Europe - Past, Present and Future. Hampshire: Palgrave Macmillan, pp. 26-52. 